\title{
En integrert forståelse av subjektive lidelser i klinisk praksis
}

\author{
I klinisk praksis møter vi ofte pasienter med helseplager som også har utfordringer på viktige livsområder \\ som samliv og arbeidsliv. Slike plager er ofte ledsaget av manglende mestringstro og vitalitet. Ved hjelp av \\ en biopsykososial helsemodell med medisinsk psykologi og stress- og mestringsteori kan vi som klinikere \\ forstå bedre, og gi mer funksjonell helsehjelp til våre pasienter.
}

\section{Aksel Tveråmo \\ post@doktoraksel.no \\ Ine Baug Johnsen \\ Eivind Meland}

e-fig 1, e-fig 2 og e-fig 4 finnes i Tidsskriftets elektroniske utgaver

Pasientens mestring av psykososiale stressfaktorer kan fremstilles som «allostatisk belastning» - balansen mellom individets mestringsressurser og de sosiokulturelle forventninger og krav som individet eksponeres for. Kontekst og biografi er avgjørende for mestring, og sårbare individer utvikler lettere mestringssvikt. Vedlikeholdende faktorer for subjektiv lidelse er negativ mestringsforventning og pessimistisk fortolkning som for eksempel hjelpeløshet og håpløshet.

Denne forståelsen kan videreutvikles til et verktøy for utredning og behandling av individer med subjektiv lidelse. Vi velger her å legge vekt på vedlikeholdende faktorer, som er det vi hovedsakelig møter i klinisk praksis og som vi har en mulighet til å intervenere i forhold til. Utløsende faktorer varierer - ulik etiologi kan gi samme vedlikeholdende faktorer.

\section{Subjektive lidelser}

Vi velger å definere subjektive lidelser som plager som pasienten rapporterer, der objektive funn ikke står i forhold til symptomene og der vi ikke har tilgjengelig teknologi som kan objektivere pasientens plager. Vi oppfatter subjektive lidelser som et gradert mål, og et kontinuum fra normale livsplager til behandlingstrengende og kronifiserte lidelser (1). Helse kan betraktes som et overskudd, og sykdom kan forstås som et underskudd av ressurser i forhold til hverdagens krav (2). Vi anerkjenner at sykdomsbegreper er perspektivavhengige og ikke kan defineres uttømmende og entydig (3). For å vinne gehør for at både leger og pasienter er medansvarlige subjekter, vektlegger vi systemiske perspektiver der sammenhenger er komplekse og gjensidig betingende. George Engel, betraktet som den biopsykososiale modellens far, understreket ofte at det var en misforståelse å se på hans modell som en summasjon av de tre nivåene biologisk, psykologisk og sosialt (4). Hans poeng var at de tre elementene var gjensidig forbundet, og at menneskelivet måtte forstås som et økologisk system der menneskets erkjennelse og meningsdanning hadde mulighet for å påvirke dette systemet (5).

\section{Dynamisk homøostase}

Menneskets helse kan betraktes som et homøostatisk system, et dynamisk likevektsforhold med bufferkapasitet i form av kompensasjonsmekanismer $(6,7)$. Patogener gir belastning og gjør pasienten syk. Salutogener gjør frisk, eller endrer forventninger og øker mestringsressurser, slik at raskere restitusjon blir mulig (8). (e-fig 1). Vi kan også forstå homøostase som en kapasitet hos individer og grupper til å tilpasse seg nye livsbetingelser og å møte utfordringer som hører til i livet.

Mennesket er omgitt av salutogener og patogener. Subjektiv og objektiv helse er god når det er likevekt mellom disse faktorene. Dette kompromisset er betingelsene for å være i live. Det er viktig å være klar over at dette ikke er en statisk likevektsmodell, men en dynamisk og gjensidig modell som forstår mennesket i en sirkulær sammenheng både som påvirket og som påvirker. Pasienten kan ikke forstås utelukkende som offer, men også som et handlende og ansvarlig subjekt.

\section{Stress- og mestringsteori}

Begrepet homøostase omfatter alle biologiske reguleringsmekanismer. Allostase omhandler reguleringen av stressaktivering ved sosial atferdstilpasning, og er derfor mer egnet til betraktning av psykososialt stress (9). Allostatisk overbelastning tilsvarer det kritiske homøostatiske punktet for psykososial overbelastning.

Når mennesket blir utsatt for en fare, reagerer det med stressresponser. Dette er medfødte og innlærte programmer som mobiliseres for å overleve faren. Programmene er hovedsakelig kamp, flukt eller tilstivning (fight-flight-freeze) (10).

Psykisk stress øker ved misforhold mellom tilpasningskrav og mestringsressurser. Vi definerer mestring av psykisk stress som de stadig tilpassede tanke- og atferdsmessige anstrengelsene som individet bruker for å hanskes med spesifikke ytre eller indre krav som oppleves som krevende eller som overgår personens ressurser (11). Men psykisk stressopplevelse kan også oppstå når kravene er mindre enn mestringsressursene, når man opplever ikke å få brukt sine evner og anlegg tilfredsstillende.

Et annet perspektiv er skillet mellom positiv og negativ responsforventning, den innlærte forventningen om hvordan man kommer til å mestre noe, heretter kalt mestringsforventning. Positiv mestringsforventning kan kalles optimisme og selvtillit som kommer av at man er vant til å mestre utfordringer. Negativ mestringsforventning kan kalles pessimisme og lav selvtillit, i ekstreme tilfeller lært hjelpeløshet $(12,13)$.

Ved en god balanse mellom individets mestringsressurser og sosiokulturelle krav vil individet mestre livsbelastningen godt og ha et lavt nivå av allostatisk belastning. Han eller hun vil ha lavt nivå av angst og depresjon, vil nyte selvtillit og ha god helse (e-fig 2).

\section{Biografi}

Pasientens biografi er beskrivelsen av hvordan han eller hun har tolket og tilpasset seg sine livshendelser. Personen er formet av livserfaringer som er skrevet inn i kroppen som fysiologisk beredskap. Resultatet av formingen kan kalles et narrativt script, en psykobiologisk «grunninnstilling», «livsinnstilling» og «mentalitet» som bestemmer en persons nivå av allostatisk belastning fra hvile til krisehåndtering (14). Scriptet utgjør en fenotype dannet som et samspill mellom genotype og miljø, der gener blir skrudd på og av gjennom tilpasning til miljøbetingel- 
Allostatisk belastning

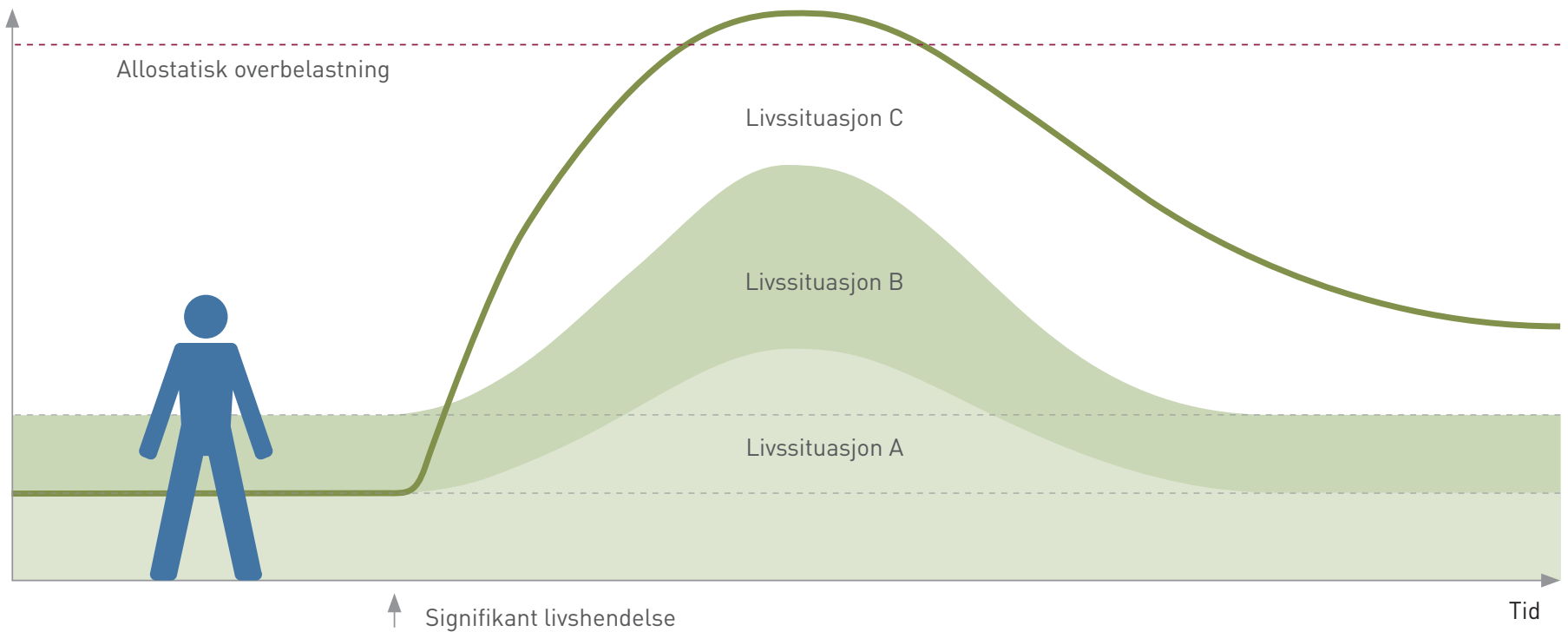

Figur 3 Modell for narrativt script: individets innlærte selvregulering av allostatisk belastning. A, B, og C er tre ulike livssituasjoner for samme individ, Ola. Ved A og B har Ola henholdsvis lav og medium allostatisk belastning. Ved en stressende livshendelse øker allostatisk belastning under mestringsprosessen, de adaptive buffersystemene fungerer godt, utgangsverdien av allostatisk belastning forblir uendret, han mestrer godt, får «gode minner» og bygger positiv mestringsforventning. I C inntrer en stressende livshendelse der bufferkapasiteten sprenges, utilstrekkelig selvregulering gir allostatisk overbelastning og utgangsverdien av allostatisk belastning innstilles på et høyere nivå. Ola har nå fått «dårlige minner» og negativ mestringsforventning, dvs. en nedsatt evne til å mestre stress som likner på den aktuelle livshendelsen. Slike psykobiologiske mønstre, biografier som samlet utgjør et narrativt script, merker Ola for livet og påvirker stress-sårbarhets-systemet og helsen

sene. Det er altså ikke snakk om «født sånn» eller «blitt sånn», det er «født sånn $o g$ blitt sånn», arv $o g$ miljø som en enhet. Det psyko-nevro-endo-immunologiske scriptet består av kognitive mønstre og en epigenetisk innstilling av nerve-, hormon- og immunsystem. Totalt sett danner dette et stress-sårbarhets-system (15) (fig 3).

\section{Biopsykososial helsemodell}

Menneskets helse beskrives i denne modellen på tre nivåer: biologisk, psykologisk og sosialt.

\section{Biologisk}

Alle somatiske strukturer er forbundet med hjernen og andre deler av sentralnervesystemet. Faget som integrerer de ulike organsystemene med hjernen kalles psyko-nevroendo-immunologi. Stress- og sårbarhetsmekanismer kan være med på å forklare hvorfor ulike mennesker utvikler stressaktiveringssymptomer fra ulike organsystemer, f.eks. dårlig regulering av tonus i det autonome nervesystemet, søvnforstyrrelser, tinnitus og økt smertefølsomhet, hypertensjon, takykardi, hjerteinfarkt, slag og muskel- og skjelettlidelser $(16,17)$.

\section{Psykologisk}

Menneskesinnet består blant annet av tanker og følelser. Evolusjonsmessig har disse vært redskaper for å tilpasse seg verden og å overleve $-\mathrm{i}$ betydningen å få flest mulige avkom. Tanker og følelser formes som interne kroppslige og fysiologiske responser og som subjektive forventninger ved internalisering av sosiokulturelle forventninger og krav (7).

Den psykologiske helsen er god når individets kognitive og emosjonelle prosesser gir nyttig tolkningsinformasjon og god tilpasning til miljøet. Fører de kognitive og emosjonelle prosessene til feiltolkning og lite funksjonell mestring, blir resultatet dårlig tilpasning til miljøet og dermed dårlig psykologisk helse. Den psykiske helsen balanserer mellom psykologiske salutogener og patogener, dvs. mellom positive drivkrefter som tro og håp, og negative drivkrefter som mistro og håpløshet. Møtet mellom ideal og realitet resulterer i en balanse mellom individets subjektive livsforventninger og samfunnets objektive livskrav.

Individets narrative script og atferdsmønstre kan forstås som stress-sårbarhet for utvikling av angst, rusavhengighet, spiseforstyrrelse og posttraumatisk stressyndrom (PTSD) $(18,19)$.

\section{Sosialt}

Vi kan forstå den sosiale dimensjonen i lys av evolusjonspsykologi. Kulturell seleksjon virker ved at atferd premieres eller straffes ut ifra sosiokulturelle forventninger og krav, med henholdsvis høy eller lav status $i$ en sosial gruppe. Ved negativ kulturell seleksjon sanksjoneres uhensiktsmessig eller uønsket atferd i gruppen først og fremst ved negativ kognitiv og emosjonell feedback fra omgivelsene. Slik sanksjonering oppleves ved fallende sosial status. Ekskluderingen fra «flokken» og «stammen» representeres ved tap av arbeid eller partner, ved fengselsdom eller andre former for sosial marginalisering og utsortering.

\section{Integrert helsemodell}

Vi kan kombinere den biopsykososiale modellen med homøostase, allostase og stress- og mestringsteori. Dette gjøres ved å anerkjenne viktigheten av balanse mellom mestringsressurser og krav i et system som er dynamisk og påvirkbart. Individets sårbarhet er uttrykt med et narrativt, psykobiologisk script, som en sum av individets biografi, et levd liv med medfødte reaksjonsmønstre og ervervede atferdsmønstre, en fenotype som er et resultat av en epigenetisk justert genotype. På det sosiale nivået er det viktig at man blir inkludert i flokken, og dette kan beskrives ved graden av sosial støtte i familien og på jobb og ved politisk og religiøs samfunnstilhørighet. Samlet utgjør dette personens biopsykososiale identitet (e-fig 4)

\section{Hva så?}

Den etiologiske tilnærmingen vi her har beskrevet, kan også være et utgangspunkt for en mer kausal behandling. Gjennom å lære å regulere allostatisk belastning kan pasien- 
ten få bedre symptomkontroll. Vi prioriterer her-og-nå-situasjonen ved å flytte fokus fra utløsende faktorer og legge vekt på reduksjon av vedlikeholdende faktorer. Psykoedukasjon kan lære pasienten å forstå plagene og å leve med dem. Teknikken er å bruke personlige erfaringer om hva som forlenger de gode fasene og forkorter de dårlige.

Vi må evne å anerkjenne pasientenes plager og opplevelse av mestringsvansker. Evne til empati er viktig, men vi må også kunne utfordre pasienter på en respektfull måte. Det kan vi for eksempel gjøre gjennom å interessere oss for hvilke verdier de står for, hva de ønsker å få ut av livet og se i hvilken grad plagsomme tanker, symptomer og handlinger hjelper eller hindrer dem i å nå sine mål i livet. Får vi en forpliktende dialog om livsvalg ut ifra mestringsressurser og sosiokulturelle krav, kan pasienten settes i stand til å handle som en mer rasjonell aktør, ta større ansvar for eget liv og i mindre grad være et offer for omstendighetene (20). Da vil klinikeren sammen med pasienten ha oppnådd en livsstilintervensjon som kan øke evnen til selvberging.

Takk til Ramona Brekkhus for utarbeiding av illustrasjoner og til Silje Endresen Reme for gjennomlesing og tips.

\section{Aksel Tveråmo (f. 1963)}

er spesialist i allmennmedisin og fastlege i Bergen.

Forfatter har fylt ut ICMJE-skjemaet og oppgir ingen interessekonflikter.

\section{Ine Baug Johnsen (f. 1966)}

er psykolog og driver egen praksis ved Nevropsykologisk Helsetjeneste, Paradis.

Forfatter har fylt ut ICMJE-skjemaet og oppgir ingen interessekonflikter.

\section{Eivind Meland (f. 1950)}

er spesialist i allmennmedisin, fastlege og professor ved Institutt for global helse og samfunnsmedisin, Universitetet i Bergen.

Forfatter har fylt ut ICMJE-skjemaet og oppgir ingen interessekonflikter.

\section{Litteratur}

1. Fink P, Rosendal M. Funktionelle lidelser: udredning og behandling. København: Munksgaard, 2012: 244
2. Helse- og omsorgsdepartementet. Piller, prioritering og politikk. NOU 1997: 7. www.regjeringen.no/ nb/dep/hod/dok/nouer/1997/nou-1997-7/5/3/ 1.html?id=343845 (22.9.2014)

3. Søvik O. Sykdomsbegrepet i historisk og dagsaktuell sammenheng. Tidsskr Nor Lægeforen 2001; 121: 2624-7.

4. Engel GL. The need for a new medical model: a challenge for biomedicine. Science 1977; 196: $129-36$

5. Meland E. Vi intervjuer George Engel: En inspirasjonskilde til humanisme i medisinen. Tidsskr Nor Lægeforen 1997; 117: 568-9

6. Cannon WB. The wisdom of the body. New York, NY: Norton \& Co, 1932: 312.

7. Damasio A Self comes to mind: Constructing the conscious brain. New York, NY: Pantheon/Random House, 2010: 367

8. Antonovsky A. The structural sources of salutogenic strengths. I: Personality and stress: Individual differences in the stress process. Oxford: John Wiley \& Sons, 1991: 67-104.

9. Schulkin J. Social allostasis: anticipatory regulation of the internal milieu. Front Evol Neurosci 2011; 2: 111.

10. Bracha HS. Freeze, flight, fight, fright, faint: adaptationist perspectives on the acute stress response spectrum. CNS Spectr 2004; 9: 679-85.

11. Lazarus RS, Folkman S. Stress, appraisal, and coping. New York, NY: Springer, 1984: 445.

12. Finamore DC. The relationship of learned helplessness, hardiness, and depression in married abused women. Diss Abstr Int B Sci Eng 2000; 60: 5770 .

13. Ursin H, Eriksen HR. The cognitive activation theory of stress. Psychoneuroendocrinology 2004 29: $567-92$

14. Danese A, McEwen BS. Adverse childhood experiences, allostasis, allostatic load, and age-related disease. Physiol Behav 2012; 106: 29-39

15. McGowan PO, Sasaki A, D'Alessio AC et al. Epigenetic regulation of the glucocorticoid receptor in human brain associates with childhood abuse. Nat Neurosci 2009; 12: 342-8.

16. Carstens JK, Shaw WS, Boersma K et al. When the wind goes out of the sail - declining recovery expectations in the first weeks of back pain. Eur J Pain 2014: 18: 269-78.

17. Stuller KA, Jarrett B, DeVries AC. Stress and social isolation increase vulnerability to stroke. Exp Neurol 2012; 233: 33-9

18. Shonkoff JP, Boyce WT, McEwen BS. Neuroscience, molecular biology, and the childhood roots of health disparities: building a new framework for health promotion and disease prevention. JAMA 2009; 301: 2252-9

19. Sekiguchi A, Sugiura M, Taki Y et al. Brain structural changes as vulnerability factors and acquired signs of post-earthquake stress. Mol Psychiatry 2013; 18: 618-23.

20. Hayes SC, Strosahl KD, Wilson KG. Acceptance and commitment therapy. The process and practice of mindful change. New York, NY: The Guilford Press, 2011.

Mottatt 3.1. 2014, første revisjon innsendt 30.6. 2014, godkjent 22.9. 2014. Redaktør: Are Brean. 